\title{
PERENCANAAN PERSEDIAAN DARAH DI UNIT TRANSFUSI DARAH (UTD) PALANG MERAH INDONESIA KOTA MADIUN
}

\author{
Halwa Annisa Khoiri, Wildanul Isnaini, Dika Restu Elyuda \\ Program Studi Teknik Industri, Fakultas Teknik, Universitas PGRI Madiun \\ Email: halwaanisa@unipma.ac.id; wildanul@unipma.ac.id; \\ restudika@gmail.com
}

Artikel masuk : 22-10-2021

Artikel direvisi : 11-11-2021

Artikel diterima : 02-12-2021

*Penulis Korespondensi

\begin{abstract}
Abstrak -- UTD PMI Kota Madiun merupakan pemasok darah untuk beberapa Bank Darah Rumah Sakit (BDRS) di wilayah Kota Madiun dan sekitarnya. Tingginya permintaan yang masuk, terkadang permintaan darah tidak dapat dipenuhi dan di sisi lain banyak juga darah yang sudah expired. Permasalahan ini dapat diselesaikan dengan menentukan stok yang aman serta kapan harus dilakukan pemesanan darah kembali. Data yang digunakan dalam penelitian ini adalah jumlah permintaan produk darah Packed Red Cells selama periode 2020 yang dikumpulkan dari database PMI. Pada penelitian ini dilakukan evaluasi sekaligus penentuan stok yang optimal untuk menghindari banyaknya darah yang rusak sekaligus mengurangi biaya persediaan dengan menggunakan metode Continuous Review System. Hasil dari penelitian ini diperoleh persediaan optimal yang harus disediakan PMI Kota Madiun sekaligus rekomendasi untuk menggunakan Two-Bin System dalam penyimpanan persediaan darah, selain itu biaya persediaan dapat berkurang sebesar $40 \%$.
\end{abstract}

Kata kunci: Continuous Review System; Darah; Out of Stock; Rantai Pasok

\begin{abstract}
UTD PMI Madiun City as a blood supplier for several Hospital Blood Banks (BDRS) in the City of Madiun and its surroundings. The large demand for blood causes stockouts and on the other hand some blood has expired. This problem can be solved by determining the safety stock and reorder point. In this study, an evaluation and determination of the optimal stock was carried out to avoid the amount of damaged blood while reducing operational costs by using the Continuous Review System method. This paper use demand of Packed Red Cells in 2020, and the data are collected from database of PMI Madiun. The results of this study obtained the optimal supply that must be provided by PMI Madiun as well as recommendations for using the Two-Bin System in storing blood supplies, and inventory costs can reduce around $40 \%$.
\end{abstract}

Keywords: Continuous Review System; Blood; Out of Stock; Supply Chain

\section{PENDAHULUAN}

Darah merupakan bagian penting dari tubuh manusia karena memiliki fungsi vital sebagai alat transportasi oksigen dan zat makanan yang diperlukan untuk kehidupan selsel. Sifat darah yang memiliki masa expired perlu mendapatkan perhatian khusus dalam pengelolaannya (Budipriyanto \& Anggraini, 2020). Berdasarkan hal tersebut, rantai pasok dalam pemenuhan darah berbeda dengan produk manufaktur. Banyak hal yang perlu diperhatikan untuk meminimalkan kerusakan darah serta memastikan ketersediaan darah ketika dibutuhkan oleh resipien (Akhdemila, 2009).

Pada supply chain terdapat kegiatan dari hulu ke hilir yang terdiri dari pemasok, distributor, hingga ke konsumen akhir. Hal yang sama terjadi pada rantai pasok darah yang mengelola aliran pasokan darah dari pendonor ke pasien, dengan pendonor sebagai pemasok, UTD PMI bertindak sebagai produsen yang melaksanakan proses donor darah, blood bank sebagai inventory dan selanjutnya didistribusikan ke rumah sakit (pasien) (Pirabán et al., 2019). Dalam rantai pasok 
darah, banyak pihak yang terlibat di dalamnya karena melibatkan para pemangku kebijakan, seperti rumah sakit, bank darah, dan pendonor (Rayendra, 2019). Karena banyaknya pihak yang terlibat, maka seringkali muncul permasalahan antara lain ketidakcocokan antara jumlah permintaan dengan ketersediaan darah yang dikarenakan tingginya angka permintaan namun jumlah pendonor semakin berkurang (Reynolds et al., 2001). Permasalahan lainnya dari rantai pasok darah adalah terjadinya overstock sehingga memperbesar jumlah darah yang dimusnahkan karena sudah rusak (Budipriyanto \& Anggraini, 2020). Karakteristik darah yang mudah rusak ini juga menjadi perhatian khusus dalam menentukan persedian agar jumlah darah tidak berlebih dan justru mengakibatkan pemborosan sumber daya (Profita, 2017).

Pada penelitian ini dilakukan analisis mengenai pengendalian persediaan darah di PMI Kota Madiun. Permintaan darah yang masuk ke PMI Kota Madiun berasal dari Bank Darah Rumah Sakit (BDRS) wilayah Madiun dan sekitarnya. Jumlah permintaan yang tidak menentu membuat PMI kesulitan dalam pengelolaan stock darah. Permasalahan lain yang muncul adalah terjadinya pandemi Covid-19 yang menurunkan jumlah pendonor aktif hampir 20\% (Wulan, 2021).

Permintaan terbesar pada tahun 2020 adalah produk darah Packed Red Cells (PRC) sebanyak 3006 kantong darah. PMI mencatat penerimaan darah di tahun 2020 mengalami penurunan padahal jumlah permintaan tinggi. Selain itu, darah yang dimusnahkan mencapai $30 \%$. Pemusnahan darah ini selain mengurangi stock juga menyebabkan biaya pengeluaran PMI menjadi besar karena darah tersebut memerlukan biaya penyimpanan sekaligus biaya kantongnya (Yul, 2019).

Analisis mengenai pengendalian stok darah dilakukan oleh Beliën \& Forcé (2012) yang membahas beberapa penelitian terkait rantai pasok darah menggunakan model Data Envelopment Analysis (DEA), model simulasi, Queuing model, dan beberapa model matematis. Dari beberapa model tersebut, model antrian dan rantai Markov dianggap paling sesuai untuk analisis rantai pasok darah karena permintaan darah yang bersifat stokastik, lead time yang tidak menentu, dan memiliki masa expired. Rayendra (2019) menganalisis mengenai rantai pasok darah di BDRS menggunakan model stokastik yaitu continuous review policy dan periodic review policy.

Dalam penelitian ini, analisis untuk pengendalian persediaan darah dilakukan dengan metode continuous review system dan selanjutnya ditentukan stock yang harus dipenuhi dengan pemisahan menggunakan two-bin system.
Metode continuous review system sesuai digunakan untuk analisis persediaan darah karena dapat mengatasi lead time dan demand darah yang berubah-ubah (Rayendra, 2019). Penerapan twobin system ini memudahkan pihak PMI dalam menentukan kapan proses reorder dilakukan dan juga memudahkan dalam mengontrol darah yang akan kadaluarsa (Yul \& Laila, 2018). Tujuan dari penelitian ini adalah mengoptimalkan pelayanan permintaan darah di PMI Kota Madiun sekaligus meminimalkan darah yang expired dengan mengetahui kapan harus dilakukan jemput bola kepada pendonor. Selain itu dilakukan perhitungan biaya total persediaan guna meminimalkan terjadinya over cost karena darah yang rusak.

\section{METODE PENELITIAN}

Penelitian ini dilakukan di PMI Kota Madiun dengan objek kantong darah Packed Red Cell (PRC) karena jenis produk darah ini yang paling banyak permintaannya. Data permintaan yang digunakan adalah permintaan pada periode Januari 2020 hingga Desember 2020.

Model yang digunakan untuk analisis pengendalian stok darah adalah model probabilistik karena sesuai dengan kondisi di lapangan dimana lead time dan demand memiliki jumlah yang tidak konstan (Heizer \& Render, 1996). Model probabilistik menggunakan Continuous Review System. Model ini menggunakan pendekatan dengan mengamati terus-menerus jumlah produksi yang dihasilkan apakah terjadi penurunan atau kenaikan. Saat terjadi penurunan dan jumlah permintaan sedang tinggi maka akan dilakukan reorder point. Safety stock (SS) dihitung untuk menyiapkan persediaan selama periode lead time (Krajweski \& Malhotra, 2016). Jumlah stok aman yang harus dipenuhi dihitung selama periode lead time diketahui melalui jumlah SS (Hafnika et al., 2016).

$$
S S=z \sigma_{d L T}
$$

Jumlah persediaan dipantau secara terusmenerus, dan saat jumlah produk mencapai titik tertentu berdasarkan nilai Reorder Point (ROP) maka dilakukan pemesanan kembali untuk memenuhi persediaan.

$$
\begin{aligned}
R O P & =\overline{d L}+S S \\
\sigma_{d L T} & =\sqrt{\bar{L} \sigma_{d}^{2}+\bar{d} \sigma_{L T}^{2}}
\end{aligned}
$$

Dimana $\bar{d}=$ rata-rata mingguan atau harian $\sigma_{L T}$ bulanan dari permintaan, $\bar{L}=$ rata-rata mıngguan atau harian atau bulanan dari lead time, $\sigma_{d}=$ standard deviasi permintaan, dan $\sigma_{L T}=$ standard deviasi lead time 
Langkah awal penelitian ini adalah melakukan observasi di PMI Kota Madiun untuk mengetahui permasalahan yang saat ini dihadapi serta menyelesaikannya dengan teori yang sesuai. Data diperoleh berdasarkan eksplorasi data untuk mengetahui rata-rata tingkat permintaan pada tahun 2020. Data yang diperoleh diolah dan dianalisis dengan menggunakan Continuous Review System sesuai dengan Persamaan 1, Persamaan 2 dan persamaan 3. Selain itu juga dilakukan penentuan persediaan dan waktu pemesanan darah yang optimal.

Selanjutnya, dilakukan penghitungan persediaan yang optimal dari model Continuous Review System. Persamaan 4 adalah rumus yang digunakan untuk menentukan jumlah persediaan optimal.

$Q=\sqrt{\frac{2 D S}{H}}$

Persediaan darah dan darah yang telah expired akan memerlukan biaya yang harus dikeluarkan yaitu digunakan untuk biaya simpan (holding cost) jika darah masih dalam kondisi baik namun belum ada permintaan masuk (Fauzi \& Bahagia, 2019). Oleh karena itu dalam penelitian ini setelah diketahui persediaan optimal, selanjutnya ditentukan biaya total persediaan atau dikenal dengan Total Inventory Cost (TIC) yang merupakan analisis biaya dari PMI dituliskan dalam Persamaan 5 (Yul \& Laila, 2018).

$T I C=\frac{Q}{2}(H)+\frac{D}{Q}(S)+(H x S S)$

Dimana $\mathrm{Q}=$ kuantitas ekonomis (Kantong), $\mathrm{D}=$ permintaan darah dalam satu tahun (Kantong), $\mathrm{S}=$ biaya pengambilan darah (Rupiah), $\mathrm{H}=$ holding cost (Rupiah) dan SS=safety stock (Kantong)

\section{HASIL DAN PEMBAHASAN}

\section{Eksplorasi Data}

Dalam penelitian ini produk darah yang dianalisis adalah Packed Red Cells (PRC) karena di unit kerja PMI Kota Madiun, produk darah ini paling banyak permintaannya. Rhesus yang digunakan dalam analisis data hanya rhesus positif karena belum ada pendonor maupun permintaan darah yang memiliki rhesus negatif. Selama periode tahun 2020 jumlah total permintaan PRC adalah 3016 kantong darah, dan dari permintaan yang masuk darah yang dapat dipenuhi adalah 2980 kantong sehingga tingkat pemenuhan kebutuhan darah adalah $98 \%$.

Golongan darah $\mathrm{O}$ menempati urutan teratas karena tingkat permintaan PRC paling tinggi, dan golongan darah $\mathrm{AB}$ menempati urutan terakhir dibandingkan dengan golongan darah lainnya (Gambar 1). Dari total 3016 kantong, jumlah permintaan darah $O$ sebanyak 1146 kantong, sedangkan golongan darah $A B$ sebanyak 203 kantong.

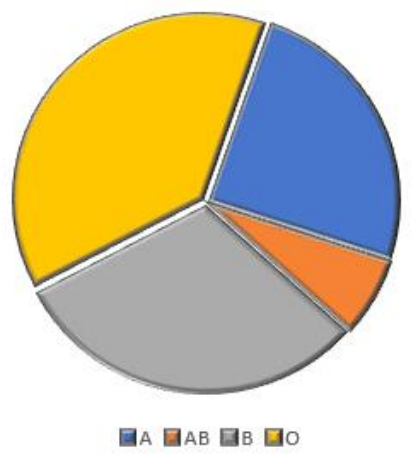

Gambar 1. Permintaan Darah Tahun 2020

\section{Analisis Safety Stock PRC}

Safety Stock dalam pengendalian persediaan penting diketahui karena akan memperkecil peluang terjadinya kekurangan stok. Besarnya safety stock ditentukan dari persentase service level, sehingga dalam penelitian ini digunakan tiga service level yaitu, $85 \%$, $95 \%$, dan $100 \%$. Nilai Z untuk service level $85 \%$ adalah 1,04 , service level $95 \%$ adalah 1,64 , dan service level $100 \%$ adalah 3,59. Semakin besar persentase service level, semakin besar pula safety stock yang dipenuhi. Safety Stock juga dipengaruhi oleh besarnya permintaan PRC yang masuk ke UTD Kota Madiun. Hasil penghitungan safety stock berdasarkan data tahun 2020 ditampilkan pada Tabel 1.

Tabel 1. Nilai Safety Stock PRC

\begin{tabular}{ccccc}
\hline Service Level & A & AB & B & O \\
\hline $85 \%$ & 8 & 3 & 6 & 16 \\
$95 \%$ & 13 & 4 & 10 & 25 \\
$100 \%$ & 29 & 9 & 21 & 54 \\
\hline
\end{tabular}

Dengan menggunakan service level $85 \%$ diketahui bahwa nilai $Z=1,04$. Rata-rata permintaan bulanan PRC golongan darah A adalah 62,17 kantong dengan standard deviasi permintaan 19,62 kantong (tidak dibulatkan dan akan dibulatkan pada hasil akhir perhitungan safety stock). Karena permintaan darah dihitung dalam periode bulanan, maka lead time juga menggunakan satuan bulanan. Untuk PRC golongan darah A diketahui bahwa rata-rata lead time nya adalah 0,16 bulan atau 4,8 hari dengan standard deviasi 0,024 bulan atau kurang dari satu hari. Nilai standard deviasi demand-lead time atau $\sigma_{d L T}$ adalah 7,95

$\sigma_{d L T}=\sqrt{\bar{L} \sigma_{d}^{2}+\bar{d} \sigma_{L T}^{2}}=\sqrt{\left(0,16 \times 19,62^{2}\right)+\left(62,17 \times 0,024^{2}\right)}=7,95$ 
Selanjutnya, dengan menggunakan persamaan 1 maka nilai safety stock untuk golongan darah $\mathrm{A}$ adalah

$\mathrm{SS}=\mathrm{Z} \times \sigma_{d L T}=1,04 \times 7,95=8$ kantong darah.

Jumlah safety stock dari masing-masing golongan darah dilakukan sebagai dasar dalam penentuan reorder point.

\section{Analisis Reorder Point PRC}

Reorder point (ROP) diperlukan dalam menentukan kapan waktu yang tepat untuk melakukan pengambilan darah. Hasil ROP yang tepat akan mengurangi risiko terjadinya stock out darah. PMI Kota Madiun hendaknya dapat menyediakan darah untuk BDRS di wilayah Madiun dan sekitarnya.

Hasil ROP yang diperoleh untuk produk darah PRC ditampilkan pada Tabel 2. Sebagai contoh rata-rata permintaan untuk golongan darah A adalah 62,17 kantong dengan rata-rata lead time adalah 0,16 bulan atau 4,8 hari, dan dengan menggunakan nilai SS sebanyak 8 kantong, maka nilai ROP untuk golongan darah A dengan service level $85 \%$ adalah

$$
\mathrm{ROP}=\mathrm{SS}+\overline{d L}=8+(62,17 \times 0,16)=18
$$

Berdasarkan hasil perhitungan diketahui bahwa ROP untuk PRC golongan darah $\mathrm{O}$ yang memiliki service level 95\% adalah 42 kantong, sehingga pihak PMI hendaknya mencari darah saat persediaan di penyimpanan darah (blood bank) PMI 42 kantong. Sama seperti safety stock, semakin besar target service level yang ditetapkan, maka semakin besar pula ROP nya, dengan kata lain periode pemesanan kembali lebih singkat.

Tabel 2. Nilai ROP PRC

\begin{tabular}{ccccc}
\hline Service Level & A & AB & B & O \\
\hline $85 \%$ & 18 & 4 & 19 & 33 \\
$95 \%$ & 23 & 6 & 22 & 42 \\
$100 \%$ & 38 & 11 & 34 & 71 \\
\hline
\end{tabular}

Untuk memudahkan pemantauan jumlah stok darah, digunakan visual review dari metode Continuous Review System yaitu Two-Bin System. Dengan menggunakan sistem ini, PMI menyediakan dua blood bank, yaitu Bin I dan Bin II. Penempatan stok darah pada Bin I dan Bin II didasarkan pada jumlah ROP untuk masingmasing golongan darah. Prinsip dari Two-bin system adalah PMI menyediakan dua penyimpanan (blood bank). Bin I berisi sejumlah nilai ROP untuk setiap golongan darah, sementara Bin II berisi kantong darah yang merupakan kelebihan dari ROP. Saat permintaan darah diterima, kantong darah dipenuhi dari Bin II. Pemesanan kembali atau pencarian darah dilakukan ketika persediaan darah di Bin II habis. Persediaan darah di Bin I digunakan untuk memenuhi permintaan selama PMI masih mencari darah.

Penggunaan Two-Bin System ini juga memperhatikan masa expired darah yang diperiksa secara berkala. Darah yang mendekati expired disimpan dalam Bin II sehingga dapat digunakan dahulu. Selanjutnya, saat persediaan darah yang baru sudah diterima, maka diisikan ke Bin I sampai mencapai nilai ROP, dan kelebihan persediaan diletakkan di Bin II untuk digunakan terlebih dahulu.

Sebagai contoh, berdasarkan Tabel 2 diketahui bahwa RPO untuk golongan darah A pada service level $85 \%$ adalah 18 kantong. Misalkan PMI memiliki persediaan 50 kantong darah $\mathrm{A}$, maka sebanyak 18 kantong ditempatkan pada Bin I dan sisanya yaitu 32 kantong ditempatkan pada Bin II. Penyusunan darah ini juga mempertimbangkan manakah darah yang akan expired terlebih dahulu. Setelah 32 kantong darah habis, maka PMI melakukan pemesanan kembali untuk dicarikan darah $\mathrm{A}$.

\section{Analisis Persediaan Maksimum}

Persediaan darah yang ada di UTD PMI Kota Madiun disimpan dalam blood bank dan akan dikeluarkan jika ada permintaan yang masuk. Jumlah persediaan maksimum dapat digunakan sebagai salah satu pertimbangan untuk menentukan pengambilan darah berikutnya. Dalam menentukan persediaan maksimum diperlukan persediaan optimal masing-masing golongan darah. Persediaan optimal untuk setiap golongan darah bergantung pada biaya pengambilan darah dan juga biaya penyimpanan darah (holding cost).

Berdasarkan informasi yang diperoleh dari UTD PMI Kota Madiun, besarnya Biaya Pengganti Pengolahan Darah (BPPD) sebesar Rp $360.000,00$. Biaya yang digunakan untuk pengambilan darah $26 \%$ dari BPPD atau sebesar Rp 93.600,00 dan biaya yang digunakan untuk penyimpanan darah adalah $24 \%$ dari BPPD atau sebesar Rp 86.400,00. Besarnya persediaan optimal untuk masing-masing golongan darah dihitung dengan menggunakan Persamaan 4, dengan hasilnya ditampilkan pada Tabel 3 . Sebagai contoh perhitungan nilai $Q$ optimal adalah untuk PRC golongan darah $A$, total permintaan (D) selama 1 tahun adalah 746 kantong. Sehingga nilai $Q$ optimal untuk A adalah

$Q=\sqrt{\frac{2 D S}{H}}=\sqrt{\frac{2 \times 746 \times 93600}{93600}}=40$ 
Tabel 3. Persediaan PRC Optimal

\begin{tabular}{cccc}
\hline $\mathbf{A}$ & $\mathbf{A B}$ & $\mathbf{B}$ & $\mathbf{0}$ \\
\hline 40 & 21 & 45 & 50 \\
\hline
\end{tabular}

Selain $Q$ optimal, diperlukan persediaan maksimal yang dapat dipenuhi oleh UTD PMI Kota Madiun berdasarkan service level yang diharapkan (Tabel 4). Jumlah persediaan maksimal diperoleh dengan menjumlahkan $Q$ optimal dengan safety stock, sehingga untuk golongan darah $A$ diperoleh nilai sebagai berikut. Persediaan $_{\max }=\mathrm{Q}+\mathrm{SS}=40+8=48$ kantong.

Tabel 4. Persediaan Maksimum PRC

\begin{tabular}{ccccc}
\hline Service Level & A & AB & B & O \\
\hline $85 \%$ & 48 & 24 & 51 & 65 \\
$95 \%$ & 53 & 25 & 54 & 81 \\
$100 \%$ & 69 & 30 & 66 & 96 \\
\hline
\end{tabular}

Setelah diketahui nilai persediaan optimal, selanjutnya dihitung Total Inventory Cost (TIC). TIC merupakan total biaya yang dikeluarkan untuk biaya persediaan, dapat ditentukan dengan menggunakan Persamaan 5. Berdasarkan harga dari BPPD, total biaya persedian adalah $\mathrm{Rp}$ $180.000,00$ per kantong darah. Nilai TIC ini dapat digunakan untuk menghitung biaya persediaan berdasarkan jumlah persediaan optimal, sehingga dapat menurunkan pengeluaran operasional UTD PMI Kota Madiun. Contoh perhitungan nilai yang digunakan adalah nilai untuk golongan darah $A$ pada service level $85 \%$, sehingga diperoleh nilai berikut.

$T I C=\frac{40}{2}(86400)+\frac{746}{40}(93600)+(86400 \times 8)$
$T I C=R p 4.185 .135,00$

Biaya persediaan per kantong diperoleh dengan membagi TIC dengan $Q$ optimal sehingga diperoleh $\mathrm{Rp}$ 104.098,00 Besarnya biaya persediaan ditampilkan dalam Tabel 5, dimana besarnya biaya ditentukan untuk setiap service level.

Tabel 5. Biaya Persediaan PRC (Rp/Kantong)

\begin{tabular}{ccccc}
\hline $\begin{array}{c}\text { Service } \\
\text { Level }\end{array}$ & A & Golongan Darah \\
\hline $85 \%$ & 104098 & 97497 & 98110 & 113326 \\
$95 \%$ & 114488 & 104011 & 104984 & 129132 \\
$100 \%$ & 147704 & 124838 & 126962 & 179665 \\
\hline
\end{tabular}

Rata-rata biaya persediaan pada beberapa service level adalah sebagai berikut, pada service level $85 \%$ biaya persediaan rata-rata adalah $\mathrm{Rp} 103.258,00$, pada service level $95 \%$ rata-rata $\mathrm{Rp} 113.154,00$, pada service level $100 \%$ rata-rata $\mathrm{Rp} 144.791,00$. Semakin besar service level maka semakin besar pula biaya persediaan yang dibutuhkan karena jumlah kantong darah yang harus disediakan juga besar. Berdasarkan informasi dari pihak PMI besarnya biaya persediaan per kantong darah adalah $\mathrm{Rp}$ $180.000,00$ sehingga dengan menggunakan metode Continuous Review System dapat menghemat biaya sebesar $43 \%$ untuk service level $85 \%$, 37\% untuk service level $95 \%$, dan $20 \%$ untuk service level $100 \%$. Selisih biaya ini dapat digunakan untuk biaya penggantian kantong darah yang expired sehingga dapat meminimalkan atau mengurangi biaya operasional PMI Kota Madiun. Pengurangan biaya operasional ini juga akan mengurangi pemborosan sumber daya yang terbatas. Penghitungan service level pada beberapa persentase dapat dijadikan pertimbangan PMI dalam menentukan stok (Gunpinar \& Centeno, 2015).

Penelitian yang dilakukan oleh Rayendra (2019) juga membahas mengenai analisis pengendalian persediaan darah dengan menggunakan metode Continuous Review System, namun belum ditunjukkan dengan menggunakan visual review sehingga dalam penelitian ini ditambahkan analisis Two-Bin System sebagai salah satu jenis visual review untuk memudahkan pihak PMI dalam mengontrol jumlah stok darah maupun darah yang akan expired. Penelitian mengenai analisis persediaan darah juga dilakukan oleh Yul \& Laila (2018) yang membahas mengenai persediaan darah hingga biaya operasional yang dapat dioptimalkan dengan metode Continuous Review System dan lead time konstan yaitu tiga hari. Dalam penelitian ini, lead time tidak konstan karena waktu permintaan darah tidak selalu sama, serta menggunakan tiga jenis service level berdasarkan informasi yang diperoleh dari pihak PMI Kota Madiun.

\section{KESIMPULAN}

UTD PMI Kota Madiun dapat menggunakan hasil dari metode Continuous Review System dalam mengendalikan persediaan darah (produk PRC) untuk meminimalkan darah yang expired dan juga meminimalkan biaya operasional. Berdasarkan nilai safety stock dan ROP dari produk PRC dapat diketahui persediaan optimal dari masing-masing golongan darah. Selain itu, berdasarkan nilai safety stock tersebut, PMI dapat mengurangi biaya persediaan sebesar $40 \%$. Pada penelitian selanjutnya, dapat ditambahkan data simulasi yang disusun mengikuti distribusi data aktualnya, untuk melihat bagaimana safety stock dan ROP pada beberapa jumlah persediaan. 


\section{DAFTAR PUSTAKA}

Akhdemila, W. (2009). Analisis pengendalian persediaan darah pada palang merah indonesia (PMI) unit transfusi darah cabang (UTDC) Kota Depok. IPB Repository. https://repository.ipb.ac.id/handle/12345678 9/15465

Beliën, J., \& Forcé, H. (2012). Supply chain management of blood products: A literature review. European Journal of Operational Research, 217(1), 1-16. https://doi.org/10.1016/j.ejor.2011.05.026

Budipriyanto, A., \& Anggraini, F. (2020). Manajemen Persediaan Darah Untuk Meminimalkan Shortage Dan Wastage Pada Bank Darah Pmi Jakarta. In Prosiding Senantias: Seminar Nasional Hasil Penelitian dan Pengabdian kepada Masyarakat (Vol. 1, No. 1, pp. 1235-1244). http://www.openjournal.unpam.ac.id/index.p $\mathrm{hp} /$ Senan/article/view/8459

Fauzi, M., \& Bahagia, S. N. (2019). Analisis Kebijakan Inventori Pada Komponen Darah Packed Red Cell (PRC). Jurnal Manajemen Industri Dan Logistik, 3(2), 94-105. https://doi.org/10.30988/jmil.v3i2.218

Gunpinar, S., \& Centeno, G. (2015). Stochastic integer programming models for reducing wastages and shortages of blood products at hospitals. Computers and Operations Research, 54, 129-141. https://doi.org/10.1016/j.cor.2014.08.017

Hafnika, F., Farmaciawaty, D. A., Adhiutama, A., \& Basri, M. H. (2016). Improvement of Inventory Control Using Continuous Review Policy in A Local Hospital at Bandung City, Indonesia. The Asian Journal of Technology Management (AJTM), 9(2), 109-119. https://doi.org/10.12695/ajtm.2016.9.2.5

Render, B., \& Heizer, J. (1996). Production and Operations Management: Strategic and Tactical Decisions. Britania Raya: Prentice Hall.

https://books.google.co.id/books?id=8RsfA QAAIAAJ

Krajewski, L. J., Ritzman, L. P., \& Malhotra, M. K.
(2010). Operations management: Processes and supply chains. Britania Raya: Pearson. https://books.google.co.id/books?id=uQbdr QEACAAJ

Pirabán, A., Guerrero, W. J., \& Labadie, N. (2019). Survey on blood supply chain management: Models and methods. Computers and Operations Research, 112. https://doi.org/10.1016/j.cor.2019.07.014

Profita, A. (2017). Optimasi Manajemen Persediaan Darah Menggunakan Simulasi Monte Carlo. Journal of Industrial Engineering Management, 2(1), 15-24. https://doi.org/10.33536/jiem.v2i1.101

Rayendra, R. (2019). Analisis Pengendalian Persediaan Produk Darah Pada Unit Pelayanan Bank Darah Rumah Sakit X Yogyakarta. Seminar Nasional Teknik Industri Universitas Gajah Mada, 95-99. http://repository.ugm.ac.id/275352/

Reynolds, E., Wickenden, C., \& Oliver, A. (2001). The impact of improved safety on maintaining a sufficient blood supply. Transfusion Clinique et Biologique, 8(3), 235-239. https://doi.org/10.1016/S12467820(01)00139-2

Wulan, E. (2021). Stok Darah di PMI Kota Madiun Menipis. RRI Kota Madiun. https://rri.co.id/madiun/daerah/1050078/stok -darah-di-pmi-kota-madiun-menipis

Yul, F. A. (2019). Pengendalian Persediaan Darah Dengan Metode Continuous Review System Pada Palang Merah Indonesia (PMI) Kota Pekanbaru. Photon: Jurnal Sain Dan Kesehatan, 9(2), 49-57. https://doi.org/10.37859/jp.v9i2.1119

Yul, F. A., \& Laila, W. (2018). Pengendalian Persediaan Darah Dan Penentuan Titik Bank Darah Rumah Sakit ( BDRS ) Yang Optimal Di Kota Pekanbaru. Seminar Nasional Teknologi Informasi, Komunikasi Dan Industri (SNTIKI-10), November, 524$528 . \quad$ http://ejournal.uinsuska.ac.id/index.php/SNTIKI/article/view/5 945 